\title{
Tidal influence on the wave-induced currents along the coastal of Gabès (Tunisia)
}

\author{
Ikram Bardi ${ }^{1}$, Mongi Souayed ${ }^{1}$, Wissem Gharbi ${ }^{1}$, Saadi Abdeljaouad ${ }^{1}$ \\ Laboratory of Mineral Resources and Environment, department of Geology, Faculty of Sciences of Tunis, \\ University of Tunis-El-Manar, University Campus, 2092, Tunisia.
}

\begin{abstract}
The sandy coast south of the Gulf of Gabès (Southern East of Tunisia) is microtidal. The tide is exceptional during spring tides. The hydrodynamics in this coastal is controlled mainly by currents induced by waves from various directions. According to the breaking angle of incidence, waves induced longshore drift and circulation cells. These are highlighted by the Coastal Modeling System (C.M.S). Thus, the most dominant waves are from the NNE and East, they produce a longshore currents directions respectively NW-SE and SE$N W$. The influence of the tide on the wave-induced currents is especially remarkable during spring high tide.
\end{abstract}

Keywords: Coastal of Gabès-coastal hydrodynamics- hydrodynamic modeling-longshore drift-tidal currents.

\section{Introduction}

The coastal studied is located south of the Gulf of Gabès (SE of Tunisia), it extends for about $20 \mathrm{kms}$ from the city of Gabès to the estuary of the wadi Ferd (Fig.1); it is marked by development of spits [1,2]. This is a microtidal sandy coast, has a low slope [3]. It is exposed to waves from the North to SE, which in breaking, create coastal currents. Most beaches are wide, dissipative with bars (Fig. 2), have a wide surf zone. On these beaches dissipation of wave energy is strong, the waves are attenuated to approach the shore and breaking is often spilling. But also we observed a plunging breaker in these beaches of Gabès. The tide in the Gulf of Gabès is semi diurnal and is the highest on the Tunisian and Mediterranean coasts, which can reach 2,3 $\mathrm{m}$ during spring high tides [4]. Tidal flood currents in the Gulf of Gabès are characterized by bifurcations; a main current directs the flow to the north, and another current to the south (Fig. 1). These tidal currents have $20 \mathrm{~cm} / \mathrm{s}$ [5].

The aim of this research is to show the influence of the tide on hydrodynamics in this coastal of the Gulf of Gabès. To do this, we have illustrated the waves- induced currents during one tide cycle (low tide and high spring tide), with hydrodynamic modeling.

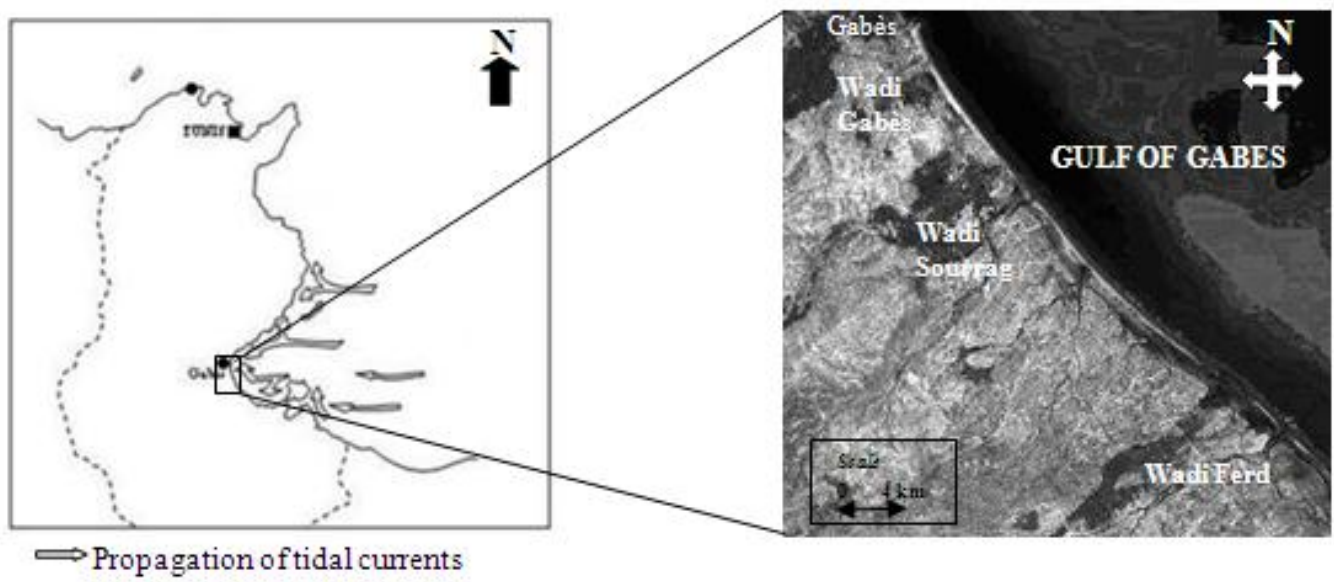

Fig. 1: Location of study area, (Google earth, 2007) (in the right); and propagation of tidal currents (HP, 1995) (in the left). 


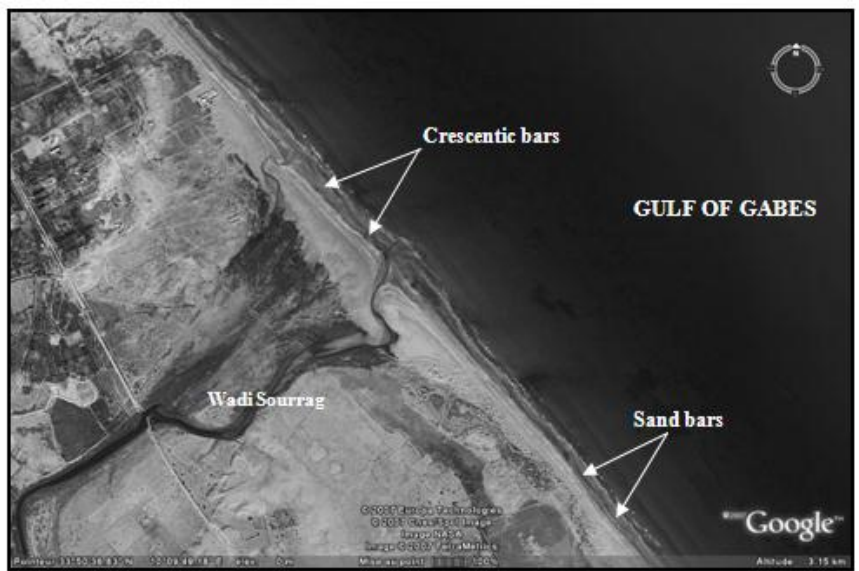

Fig.2: Crescentic bars on the foreshore zone, on the coast of Gabès (Google earth, 2007)

\section{Methodology}

In this research the approach is a uni-linear mathematical model, that treats the coastal hydrodynamics through the coastal modeling system (C.M.S). This is a model Coastal Management provided by the Engineering and Coastal Oceanography Group (G.I.O.C) from the University of Cantabria in Spain [6]. The C.M.S is composed of modules that allow a hydrodynamic study of the coastal. The long-term analysis is studied using models of Medina \& al. [7], and Gonzalez \& Medina [8]. The short-term analysis using a series of programs, grouped under the name "Mopla" (Model Morphodynamics of the coastal). We applied the module "Mopla" with sub module "Oluca sp" and "Copla sp" to simulate the propagation of waves and the currents induced by breaking waves

\section{Results And Discussions}

The waves that propagate in the Gulf of Gabès are from different sectors. These from the East, NNE and $\mathrm{NE}$ are the most frequents and the highest (significant wave height: $\mathrm{Hs}=1,5 \mathrm{~m}$ ). The waves from the $\mathrm{SE}$ are infrequent and weak $(\mathrm{Hs}=0,5 \mathrm{~m}$ and wave period: $\mathrm{Tp}=7 \mathrm{~s}$ ). After breaking on the sandy beach, waves determine coastal currents, which the nature and sedimentary effects depend mainly on the angle of the incidence compared to the coastline [9]. The propagation of these currents is simulated by the model C.M.S in the following figures by vectors.

\section{- Currents generated by waves from the North}

During low tide $(0,3 \mathrm{~m})$, the wave from the NNE breaking obliquely, create a longshore drift directed toward the SE. Locally we observed a weak circulation cells (Fig. 3 A). In addition, during spring high tide (2,3 $\mathrm{m})$ wave induced-currents are the same (longshore direction NW/SE) but with more agitation and circulation cells currents are strengthen (Fig. $3 \mathrm{~B}$ ). The frontal wave from the NE, breaking parallel over the nearshore bars create circulation cells that generate rip currents (Fig.4 A). At high tide, these currents are reinforced (Fig.4 B).

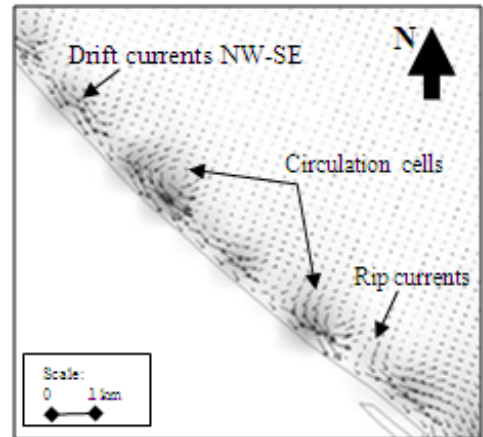

Fig. $3 \mathrm{~A}$ : currents produced by waves from NNE along the coastal of Gabès, at low tide: $(\mathrm{LT}=0,3 \mathrm{~m})$

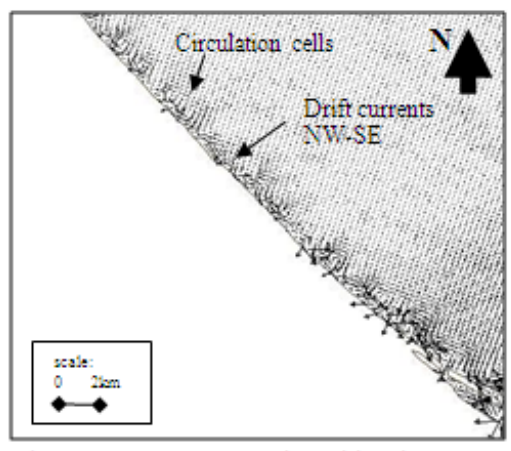

Fig.3 B: Currents produced by the NNE waves reinforced by the influence of high tide $(\mathrm{HT}=2,3 \mathrm{~m})$ 


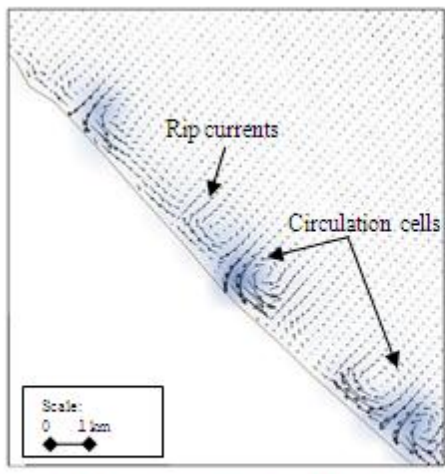

Fig. $4 \mathrm{~A}$ : currents induced by the NE waves, at low tide $(\mathrm{LT}=0,3 \mathrm{~m})$

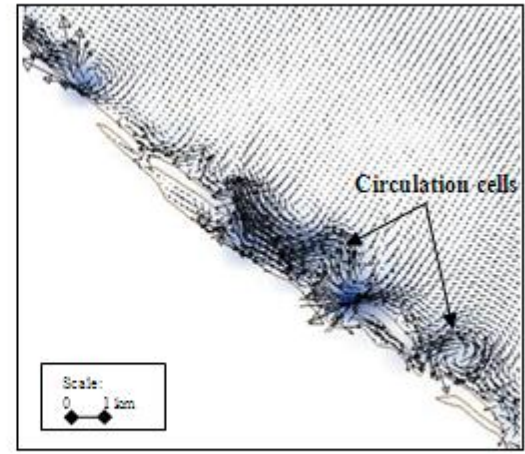

Fig. $4 \mathrm{~B}$ : currents produced by the NE waves at spring high tide ( $\mathrm{HT}=2,3 \mathrm{~m})$

\section{- Currents generated by waves from the East}

The breaking wave from the East is oblique, create a strong longshore drift directed SE/NW [10] (Fig. 5 A). At spring high tide, these currents are stronger (Fig. $5 \mathrm{~B}$ ). Waves from ESE ( $\mathrm{Hs}=0,5 \mathrm{~m}$ ) break with a relatively low incidence angle, produce at low tide a weak longshore drift directed SE / NW (Fig. 6 A). But the remarkable fact is that during spring high tide, the wave-induced currents are masked by tidal currents which are directed towards the SE (Fig. 6 B). These simulations were also observed for SE swells ( $\mathrm{Hs}=0,5 \mathrm{~m}$ ), where the tidal current dominate the weak longshore current induced by waves [3].

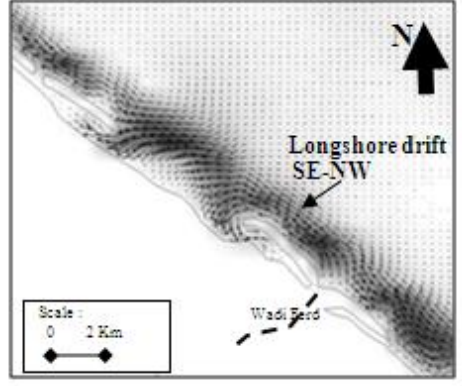

Fig. 5 A: Longshore drift produced by the $\mathrm{E}$ waves $(\mathrm{LT}=0,3 \mathrm{~m})$

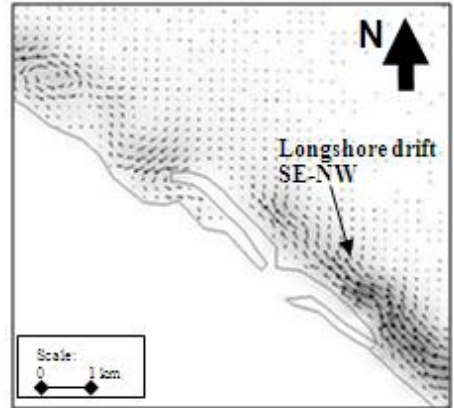

Fig. $6 \mathrm{~A}$ : Longshore drift produced by the ESE waves $(\mathrm{LT}=0,3 \mathrm{~m})$

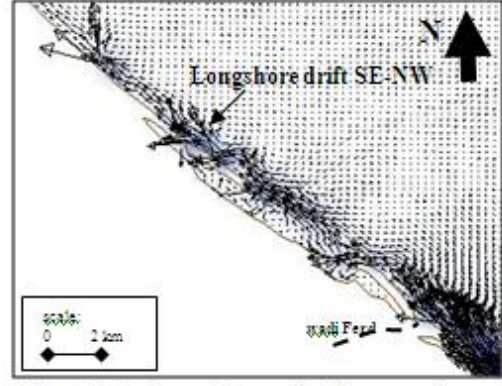

Fig. 5 B: Longshore drift strengthen produced by the $\mathrm{E}$ waves ( $\mathrm{HT}=2,3 \mathrm{~m}$ )

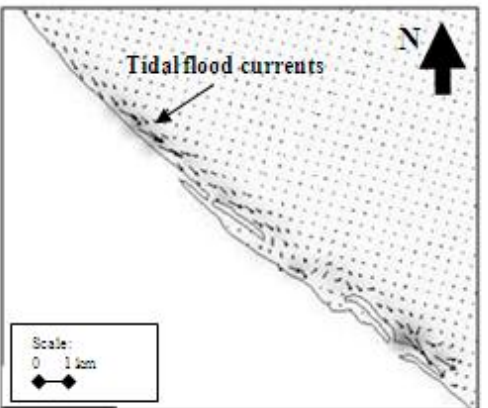

Fig. 6 B: Tidal current dominate longshore induced by ESE waves, at spring high tide $(\mathrm{HT}=2,3 \mathrm{~m})$

The simulations show that the tide level affects the stability of the wave-induced currents circulation, resulting different behaviors of the circulation cells and especially of longshore currents during one tide cycle. Thus, the tidal currents in the Gulf of Gabès are not negligible, especially at spring high tide; they disrupt the currents generated by waves and even they dominate. On short waves $(\mathrm{Hs}=0,5 \mathrm{~m})$ typically for swells directions ESE and SE, the weak drift currents induced are disrupted during one tide cycle. Indeed, during spring high tide, these currents are masked. This is because the tidal flood currents dominate the weak longshore currents. While, for energy waves directions NNE and $\mathrm{E}(\mathrm{Hs}=1,5 \mathrm{~m})$, the influence of the tide is to strengthen drift currents and circulation cells induced by these waves. Thus, the hydrodynamics intensifies with tide level. In addition, the most dynamic waves are from the NNE and $\mathrm{E}$ and have the most impact on the morphological of 
the coastal [3]. The longshore drift NW-SE and SE-NW, produced respectively by these waves, are the most effective, they contribute to the formation and development of spits along the coastal [10,11].

Also, the simulation show the presence of circulation cells currents over the nearshore and foreshore bars, especially during swells NE and NNE. In breaking on sand bars, waves will force large cells currents (Fig.4A, B). These are associated with rip currents at each channel. In addition, the intertidal zone is marked by crescentic and longitudinal sand bars (Fig. 2) interspersed with rip channels, through which rip currents drained sediment seaward [3]. These cells play an essential role in the dynamics of sandy coasts. The circulation cells disappear following the incidence of the waves from E and ESE; then a longshore current takes place (Fig.5A, B and Fig. 6 A).

Therefore, the presence of nearshore bars induces a focusing of wave energy and the formation of rip currents. When the waves break, they push water to the shore, and then go more easily evacuated by the drainage channels [12]. Noting that, rip currents play an important role in the coastal morphodynamics [13, 14].

\section{Conclusion}

Through this research we have shown that in one tide cycle, the hydrodynamics in the south coast of Gabès is sensitive to the wave and tide conditions. According to the angle of incidence, wave induced longshore drift which play a vital role in coastal hydrodynamics. Breaking on the sand bars, waves induced circulation cells mainly for frontal wave from the NE. tidal currents contribute to the hydrodynamics mainly at spring high tide, thus they strengthen the currents induced by waves and then amplify the hydrodynamics.

\section{Acknowledgements}

The authors wish to thank Ms.Radhia Souissi from laboratory of mineral resources and environment of faculty of Tunisia; and the coastal oceanographic engineering group (G.I.O.C) from the University of Cantabria in Spain.

\section{References}

[1] Bardi I., Souayed M. \& Abdeljaouad S., Evolution des flèches littorales le long d'une côte sableuse microtidale : Cas de la flèche sud d'Oued Sourrag (Golfe de Gabès, Tunisie), Proc. ${ }^{\text {st }} \mathrm{CM}^{2}$, Conf. Internat., Tunisia, (1), 2009, 87-90.

[2] Bardi I., Souayed M., Abdeljaouad S. Gharbi W. \& Souissi R., Evolution morphodynamique de la côte sableuse microtidale dans la partie sud du Golfe de Gabès : Cas de l'estuaire de l'oued Ferd (Sud de la Tunisie), Proc. XI èmes JNGCGC, Conf, France, (11), 2010, $163-170$

[3] Bardi I., Morphodynamique de la côte sableuse microtidale à barres le long de la frange littorale Gabès-Oued Ferd, (Golfe de Gabès-Tunisie), PhD Thesis, Faculty of sciences of Tunis, University of Tunis El Manar Tunisia, 2010.

[4] O.T.C, Office of Topography and Cartography, Tide calendar of Gabès, Tunisia, Report, 2005.

[5] H. p, portugaise, Etude générale pour la protection du littoral tunisien, Minis. Infra. Tunisia, Report, (1), 1995, 1-78.

[6] G.I.O.C, Group Oceanographic and Coastal Engineering, Manuel de l'utilisateur de S.M.C, University of Cantabria, Directorate General of Coasts, Ministry of the Environment, Spain, 2005.

[7] Medina R., Bernabeu A.M., Vidal C., Gonzalez M., Relationship between beach morphodynamics and equilibrium profiles,Proc. $27^{\text {th }}$ Int. Coastal Eng. Conf, ASCE, 2000, 2589-2600.

[8] Gonzalez M., Medina R., On the application of static equilibrium bay formulations to natural and man-made beaches. Coastal Engineering, (43), 2001, 209-225.

[9] Chamley H., Les milieux de sédimentations : Les milieux marins côtiers (Edit. Dunod, 1986).

[10] Bardi I., Gharbi W, Souayed M. \& Abdeljaouad S., Sediment dynamics of the coast of Gabes, Proc. of the Global Congress on ICM, EMECS 10-MEDCOAST Turkey, 2013,(2), 1305-13011.

[11] Bardi I., Souayed M. \& Abdeljaouad S., Evolution of the sandy coast of Gabes, S-E of Tunisia, International Journal IOSR-JESTFT (5), 2013, 17-18.

[12] Castelle B., Modélisation de l'hydrodynamique sédimentaire au-dessus des barres sableuses soumises à l'action de la houle: application à la côte aquitaine, PhD Thesis, univ. Bordeaux I, 2004.

[13] Sonu C., Field observation on nearshore circulation and meandering currents. Journal of Geophysysical Research, (77), 1972, 32323247.

[14] Wright L. and Short A., Morphodynamic variability of surf zone and beaches: a synthesis, Marine Geology, (56), 1984, 93-118. 